\title{
Mediating Effect of Organisational Culture between Leadership Values on Innovation: A Partial Least Squares (PLS) Path-Modeling
}

\author{
Mokhtar Abdullaha, Mohd Rashid Ab Hamidb*, Zainol Mustafac, Fazli Idris ${ }^{\mathrm{d}}$, Nur Riza Mohd Suradic \\ ${ }^{a}$ Faculty of Defence and Management Studies, National Defence University of Malaysia (UPNM), Kem Sg. Besi, 53000 Kuala Lumpur \\ ${ }^{b}$ Faculty of Industrial Sciences \& Technology, Universiti Malaysia Pahang, Lebuhraya Tun Razak, 26300 Kuantan, Pahang \\ 'School of Mathematical Sciences, Faculty of Science \& Technology, National University of Malaysia, 43600 Bandar Baru Bangi, Selangor \\ ¿UKM-Graduate School of Business (GSB), National University of Malaysia, 43600 Bangi, Selangor
}

*Corresponding author: mrahrashq@gmail.com

\section{Article history}

Received :21 January 2013

Received in revised form :

7 May 2013

Accepted :25 June 2013

\section{Graphical abstract}

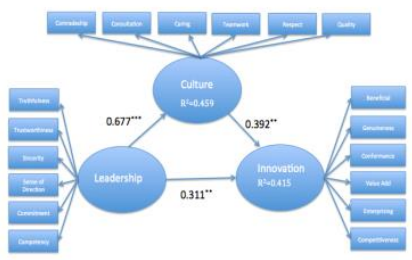

\section{Abstract}

This exploratory study examined how leadership values affect innovation through organizational culture in organisations. A model of these relationships was created based on earlier research on value-based leadership and culture and a sample of 390 managers and personnel of Government-link companies in Malaysia. The model was assessed using Partial Least Squares (PLS) based Structural Equation Modeling (SEM). Analyses with the PLS technique confirmed all the hypotheses concerned. The results generally support significant relationships between leadership values, organisational culture and innovation. The study also confirmed the mediating role of organizational culture for the relationship between leadership values and innovation in organisations. The role of organizational culture is important for understanding how leadership values and innovation are related. The results of the study also suggest several aspects that may help organisations create conducive working environment supportive of innovation.

Keywords: Leadership Values; organisational culture; innovation; mediating effect; values; partial least squares

\begin{abstract}
Abstrak
Kajian penerokaan ini memeriksa bagaimana nilai-nilai kepimpinan menjejaskan inovasi melalui budaya organisasi dalam sesebuah organisasi. Sebuah model bagi hubungan ini telah dicipta berdasarkan penyelidikan awal mengenai kepimpinan berasaskan nilai dan budaya dan sampel 390 pengurus-pengurus dan kakitangan syarikat-syarikat berkaitan kerajaan di Malaysia. Model ini telah dinilai menggunakan Kuasa Dua Terkecil Separa (PLS) berdasarkan Pemodelan Persamaan Berstruktur (SEM). Analisis dengan teknik PLS mengesahkan semua hipotesis berkenaan. Keputusan secara umumnya menyokong hubungan penting antara nilai-nilai kepimpinan, budaya organisasi dan inovasi. Kajian ini juga mengesahkan peranan pengantara budaya organisasi untuk hubungan antara nilai-nilai kepimpinan dan inovasi dalam organisasi. Peranan budaya organisasi adalah penting untuk memahami bagaimana hubungkait antara nilai-nilai kepimpinan dan inovasi. Hasil kajian ini juga mencadangkan beberapa aspek yang boleh membantu organisasi dalam mewujudkan persekitaran kerja yang kondusif menyokong inovasi.
\end{abstract}

Kata kunci: Nilai-nilai kepimpinan; budaya organisasi; inovasi; kesan pengantara; nilai-nilai; kuasa dua terkecil separa

\subsection{INTRODUCTION}

In today's era of globalisation, many organisations are forced to focus on many issues that affect their survival. Organisations are trying to search for strategies and practices that will enable them to survive in an increasingly complex, competitive, and global marketplace. Innovation is widely regarded as vital to organisational, indeed national economic health (Innovation and Business Skills Australia, 2004). As innovation becomes critical to the survival of these organizations, it is important that managers know how to shape and influence the work environment to make it conducive to creativity and innovation (Jaskyte, 2004). One of the major factors repeatedly suggested to affect innovation is leadership (King, 1990; Osborne, 1998; Schin \& McClomb, 
1998; Schein, 2004). Leaders can create and manage an organizational culture that promotes innovation, can be product champions or heroic innovators who support innovation throughout the process of its implementation, and can create organizational structure needed to support innovativeness (Peters \& Waterman, 1982; Van de Ven \& Andrew, 1986). Damanpour and Schneider (2006) asserted that strategic leadership research indicates that top managers influence organizational outcomes by establishing organizational culture, influencing organizational climate, and building the capacity for change and innovation.

In this regard, the purpose of exploratory study examined in this article was to investigate leadership values, organizational culture, and innovation in a sample of government-linked companies in Malaysia. More specifically, the study sought to answer the following research questions:

(1) What is the relationship between leadership values and organizational innovativeness?

(2) What is the relationship between leadership and organizational culture?

(3) What is the relationship between organizational innovativeness and organizational culture?

(4) Does organizational culture act as a significant mediating factor in the relationship between leadership and innovation?

\subsection{MATERIALS AND METHODS}

\subsection{Methodology}

The focus of this study is on the value-based leadership and culture in government-link companies (GLCs) in Malaysia. A total of six GLCs were identified for the study. This study utilised both qualitative and quantitative methods. The use of both methods can enhance understanding of social phenomena (Creswell, 1998). Qualitative methods were used in the first stage to provide an understanding of the contextual background for core values internalisation in those GLCs. Quantitative methods were used in the second stage primarily for confirmatory analysis, including hypothesis testing. In the first stage of data collection, a briefing was given to six GLCs heads or the corporate section managers on the purpose of this research. In the second stage of data collection, questionnaires were distributed to managers and executives in the six GLCs through the appointed coordinators. The respondents were asked to rate the extent to which the 'visibility' of core values being internalized in their respective organisations on a 5-point Likert scale. A total of 450 questionnaires were returned. However, due to the use of listwise treatment of missing values, a final 390 questionnaires were utilized for data analyses. The pilot test revealed that all measurement scales used in the study had Cronbach's alpha above 0.70 as generally accepted lower limit (Hair et al., 2010) and exceeds 0.60 as suggested by Nunnally and Bernstein (1994).

\subsection{Air Pollution Index (API)}

In this study, path diagrams showing relationships among three constructs: 1) Leadership, 2) Organisational Culture, and 3) Innovation are examined and depicted in Figure 1. A model of these relationships was created based on earlier research by Hamid et al. (2010 \& 2011). These variables denote the theoretical constructs of the relationships which are to be tested empirically. Observed or measured variables for these constructs are then developed as discussed. Six observed variables or indicators for Leadership values: 1) Truthfulness, 2)
Trustworthiness, 3) Sincerity, 4) Sense of Direction, 5) Commitment, and 6) Competency are selected. Six indicators for organisational culture are identified. They are perception of 1) Comradeship, 2) Consultation, 3) Caring, 4) Teamwork, 5) Respect, and 6) Quality. 1) Beneficial, 2) Genuineness, 3) Conformance, 4) Value Add, 5) Enterprising, and 6) Competitiveness are six indicators of Innovation. The respective values-based indicators and the descriptions/items for this study are summarised in Tables 1a-c.

Table 1 (a) Value-based indicators for leadership values

\begin{tabular}{|c|c|c|}
\hline Constructs & Values & Items \\
\hline \multirow{6}{*}{ Leadership } & Truthfulness & $\begin{aligned} \text { L1: Our leaders take risks for } \\
\text { every decision taken } \\
\text { without fear or favour in } \\
\text { order to assure business/ } \\
\text { organisational success. }\end{aligned}$ \\
\hline & Trustworthiness & $\begin{array}{l}\text { L2: Our leaders will ensure } \\
\text { that whatever tasks } \\
\text { assigned will be } \\
\text { accomplished as planned } \\
\text { / scheduled / budgeted by } \\
\text { the organisation. }\end{array}$ \\
\hline & Sincerity & $\begin{array}{l}\text { L3: Actions taken by our } \\
\text { leaders are always in the } \\
\text { best interest of the whole } \\
\text { organisation. }\end{array}$ \\
\hline & Sense of Direction & $\begin{array}{l}\text { L4: Actions taken by our } \\
\text { leaders are in line with } \\
\text { organisational goals. }\end{array}$ \\
\hline & Commitment & $\begin{array}{l}\text { L5: Our leaders consistently } \\
\text { provide the guidance, } \\
\text { means and } \\
\text { encouragement for the } \\
\text { people to achieve } \\
\text { success. }\end{array}$ \\
\hline & Competency & $\begin{array}{l}\text { L6: Our leaders are capable of } \\
\text { planning, organising, } \\
\text { leading and controlling } \\
\text { the organisation. }\end{array}$ \\
\hline
\end{tabular}

Table 1 (b) Value-based indicators for culture values

\begin{tabular}{|c|c|c|}
\hline Constructs & Values & Items \\
\hline \multirow{6}{*}{$\begin{array}{l}\text { Organisational } \\
\text { Culture }\end{array}$} & Comradeship & $\begin{array}{l}\text { C1: Relationships among the } \\
\text { employees at all levels in } \\
\text { this organisation are based } \\
\text { on the spirit of } \\
\text { brotherhood. }\end{array}$ \\
\hline & Consultation & $\begin{aligned} \mathrm{C} 2: & \text { Views of others are } \\
& \text { consulted in decision } \\
& \text { making process. }\end{aligned}$ \\
\hline & Caring & $\begin{array}{l}\text { C3: Caring culture exists in } \\
\text { this organisation. }\end{array}$ \\
\hline & Teamwork & $\begin{array}{l}\text { C4: Teamwork is being } \\
\text { practiced in this } \\
\text { organisation. }\end{array}$ \\
\hline & Respect & $\begin{array}{l}\text { C5: People's ideas are } \\
\text { respected no matter what } \\
\text { position they hold or at } \\
\text { which level they sit. }\end{array}$ \\
\hline & Quality & $\begin{array}{l}\text { C6: Services provided receive } \\
\text { positive evaluations by } \\
\text { customers or stakeholders }\end{array}$ \\
\hline
\end{tabular}


Table 1 (c) Value-based indicators for innovation values

\begin{tabular}{|c|c|c|}
\hline Constructs & Values & Items \\
\hline \multirow{6}{*}{ Innovation } & Beneficial & $\begin{array}{l}\text { I1: Only new ideas that will benefit } \\
\text { end-users are considered by the } \\
\text { management. }\end{array}$ \\
\hline & Genuineness & $\begin{array}{l}\text { I2: The new products and services } \\
\text { developed by the organisation } \\
\text { are always unique and based on } \\
\text { original ideas. }\end{array}$ \\
\hline & Conformance & $\begin{array}{l}\text { I3: New products are required to } \\
\text { undergo tests for conformance } \\
\text { with specified standards or } \\
\text { regulations. }\end{array}$ \\
\hline & Value Add & $\begin{array}{l}\text { I4: Only innovative ideas that have } \\
\text { value-added are taken into } \\
\text { account by the management for } \\
\text { further development. }\end{array}$ \\
\hline & Enterprising & $\begin{array}{l}\text { I5: In this organisation people are } \\
\text { encouraged to introduce } \\
\text { products and services that have } \\
\text { potential market. }\end{array}$ \\
\hline & Competitiveness & $\begin{array}{l}\text { I6: The new product and services } \\
\text { introduced by the organisation } \\
\text { are always well known in the } \\
\text { market. }\end{array}$ \\
\hline
\end{tabular}

\subsection{RESULTS AND DISCUSSION}

\subsection{The Measurement Model}

The research model of Figure 1 was analyzed using SmartPLS 2.0, a PLS structural equation modeling tool (Ringle et al., 2005). The measurement model in PLS is assessed in terms of item loadings and reliability coefficients (composite reliability), as well as the convergent and discriminant validity. Individual item loadings greater than 0.7 are considered adequate (Fornell and Larcker, 1981). Interpreted like a Cronbach's alpha for internal consistency reliability estimate, a composite reliability of 0.7 or greater is considered acceptable (Fornell and Larcker, 1981). The average variance extracted (AVE) measures the variance captured by the indicators relative to measurement error, and it should be greater than .50 to justify using a construct (Barclay et al., 1995). The discriminant validity of the measures (the degree to which items differentiate among constructs or measure distinct concepts) was assessed by examining the correlations between the measures of potentially overlapping constructs. Items should load more strongly on their own constructs in the model, and the average variance shared between each construct and its measures should be greater than the variance shared between the construct and other constructs (Compeau et al., 1999). The structural model in PLS is assessed by examining the path coefficients (standardized betas). $t$ statistics are also calculated to assess the significance of these path coefficients. In addition, $\mathrm{R}^{2}$ is used as an indicator of the overall predictive strength of the model. The PLS path model and the measurement results are summarised in Figure 2.

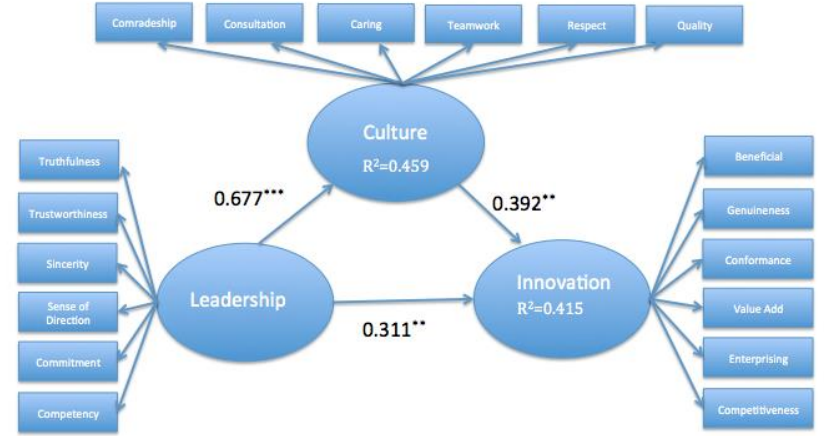

Figure 2 Results of PLS path model estimation

Table 4 PLS output - item loadings

\begin{tabular}{cccc}
\hline Indicators & Leadership & $\begin{array}{c}\text { Organisational } \\
\text { Culture }\end{array}$ & Innovation \\
\hline L1 & $\mathbf{0 . 7 0}$ & 0.47 & 0.37 \\
L2 & $\mathbf{0 . 8 0}$ & 0.51 & 0.47 \\
L3 & $\mathbf{0 . 8 4}$ & 0.59 & 0.51 \\
L4 & $\mathbf{0 . 8 4}$ & 0.51 & 0.50 \\
L5 & $\mathbf{0 . 8 2}$ & 0.59 & 0.48 \\
L6 & $\mathbf{0 . 8 2}$ & 0.58 & 0.45 \\
C1 & 0.47 & $\mathbf{0 . 7 7}$ & 0.37 \\
C2 & 0.57 & $\mathbf{0 . 8 0}$ & 0.51 \\
C3 & 0.52 & $\mathbf{0 . 8 3}$ & 0.43 \\
C4 & 0.57 & $\mathbf{0 . 8 1}$ & 0.42 \\
C5 & 0.59 & $\mathbf{0 . 8 1}$ & 0.53 \\
C6 & 0.46 & $\mathbf{0 . 6 9}$ & 0.54 \\
I1 & 0.44 & 0.40 & $\mathbf{0 . 6 9}$ \\
I2 & 0.47 & 0.45 & $\mathbf{0 . 7 6}$ \\
I3 & 0.32 & 0.37 & $\mathbf{0 . 7 1}$ \\
I4 & 0.45 & 0.46 & $\mathbf{0 . 7 9}$ \\
I5 & 0.41 & 0.42 & $\mathbf{0 . 7 4}$ \\
I6 & 0.42 & 0.52 & $\mathbf{0 . 7 1}$ \\
\hline
\end{tabular}

Table 5 Reliability, convergent and discriminant validity coefficients

\begin{tabular}{lccccc}
\hline & CR & AVE & $\mathbf{1}$ & $\mathbf{2}$ & $\mathbf{3}$ \\
\hline 1. Leadership & .916 & .647 & $\mathbf{. 8 0 4}$ & & \\
2. Org. & .907 & .619 & .677 &. $\mathbf{7 8 7}$ & \\
Culture & & & & & \\
3. Innovation & .875 & .540 & .576 & .601 & $\mathbf{. 7 3 5}$ \\
\multicolumn{2}{l}{ CR: Composite Reliability; AVE: Average Variance Extracted. }
\end{tabular}

Diagonal Elements are the square root of the variance shared between the constructs and their measurement (AVE). Off diagonal elements are the correlations among constructs. Diagonal elements should be larger than off-diagonal elements in order to dbtain the discriminant validity. 
The results show that, except for C6 and I1, all other item loadings were above the suggested 0.70 (Table 4). However, items C6 and I1 were not dropped because the internal reliabilities assessed by composite reliability were greater than 0.70 (see Table 5). Table 5 also demonstrates satisfactory convergent and discriminant validity of the measures. Average variance extracted (AVE) for all constructs exceeded 0.50. As for the discriminant validity, Table 5 shows that all constructs were more strongly correlated with their own measures than with any of the other constructs. Thus, the discriminant validity of the constructs is achieved.

\subsection{The Structural Model}

The estimated path coefficients from the PLS analysis are shown in Figure 2. Hypotheses $\mathrm{H} 1, \mathrm{H} 2$ and $\mathrm{H} 3$ were all supported. With a weight of 0.576 , the Leadership values expresses the largest explanatory share, while the weight of the Organisational culture is slightly lower $(0.316)$. To determine the significance of all the relationships in the model, resampling techniques such as bootstrapping procedure was applied (Henseler et al., 2009). The bootstrapping procedure allows for t-tests to be carried out on each of the relationships. Based on the $t$-test statistics Leadership values demonstrated a direct, statistically significant, and positive effect on Organisational Culture (H1 p<.001). Similarly, as hypothesized, Leadership values have a direct, statistically significant, and positive impact on Innovation $(\mathrm{H} 2$ $\mathrm{p}<0.001)$. Its impacts was fully mediated by Organisational Culture, which had a significant direct effect on Innovation (H3 $\mathrm{p}<.01)$.

Table 6 Structural path coefficilents

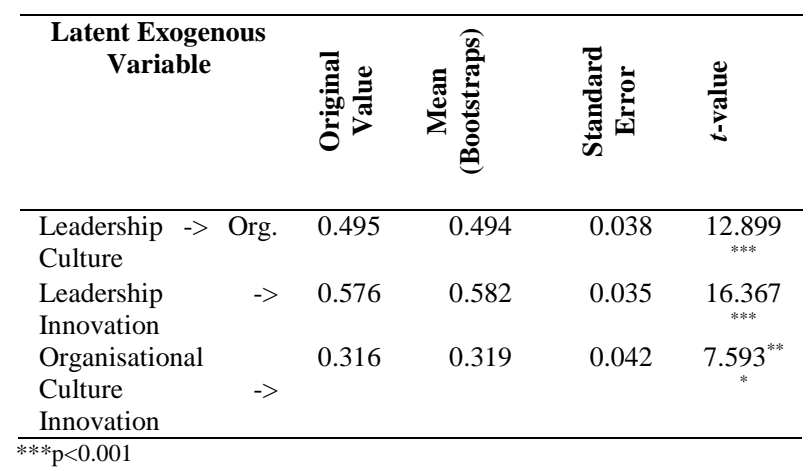

The goodness-of-fit $\mathrm{R}^{2}$ of the latent endogenous variables can be used to evaluate the utility of the proposed model. In the proposed Model, 33.2\% of variance in Innovation was explained by the leadership and culture values. In addition, $52.5 \%$ of variance in Organisational Culture was explained by Leadership values itself. For a more detailed analysis, a computation of the effect size $f^{2}$ approximates the two constructs' predictive power regarding the innovation. If the analysed exogenous latent variable in the structural model is either excluded or included, relative changes in the goodness-of-fit $\mathrm{R}^{2}$ define the effect size. According to Chin (1998), $f^{2}$ values of $0.02,0.15$ and 0.35 specify whether latent exogenous variables have a small, medium or large effect. Based on the preceding results, the Leadership values $(0.085)$ have a small effect at the structural level, while the effect of the Organisational culture (0.151) is medium.

\subsection{CONCLUSION}

In this article, a theoretical model of the relationship between leadership values, organisational culture and innovation in Malaysian GLCs was developed and analysed. The focus of this paper was to examine the mediating effect of the organizational culture in the leadership-innovation relationship. The results of this study seem to suggest that in order for the organizations to become more innovative, leaders would have to internalize leadership values that will help shape the culture of their organizations. The results also emphasise the need for managers and subordinates to understand and internalise the culture of their organization and seek to develop values, skills and practices that are supportive of innovation. By developing cultures that foster innovation, managers can help their organizations become more responsive to the changes in the external environment and become more competitive.

Numerous scholars (Howell and Higgins, 1990; Schin and McClombe, 1998) asserted that several aspects of leadership practices that would promote innovation in their organisations include: reward for creative ideas, risk taking, forward looking, searching for innovation and potential influence, experimenting with new concepts and procedures, studying emerging social and economic trends, committing to vision-supporting innovation, and pursuing unconventional action plans. As Drucker (1994) pointed out that organizations characterised by deeply embedded leadership practices and organisational values risk success because they can stop questioning the need to change and respond to the external environment.

\section{Acknowledgement}

The authors gratefully acknowledged the financial support received in the form of a research grant from Universiti Kebangsaan Malaysia under (UKM DLP 2011 081).

\section{References}

[1] Ab Hamid, M. R., Mustafa, Z., Suradi, N. R. M, Abdullah, M., Idris, F., Ismail W.R., Ali, Z. and Zainal Abidin, M. 2010. Measuring Leadership Values Based On Value-based Total Performance Excellence Model (VBTPEM). Business Management Quarterly Review. 1(3): 64-79.

[2] Ab Hamid, M. R., Mustafa, Z., Idris, F., Abdullah, M., Suradi, N. R. M and Ismail, W. R. 2011. Multi-factor of Cultural Values: A Confirmatory Factor Analytic Approach. International Journal of Methodology: Quantity \& Quality. 44(1): DOI 10.1007/s11135-0119532-z.

[3] Alhabshi, S. O. 2003. Values-based leadership: its significance to modern organisations. In Nik Mustapha Hj. Nik Hassan (eds.), Valuesbased management - the way forward for the next millennium, (Institute of Islamic Understanding of Malaysia, Kuala Lumpur)

[4] Anderson, M. and Sohal, A. S. 1999. A Study of the Relationship Between Quality Management Practices and Performance in Small Businesses. International Journal of Quality \& Reliability Management. 16(9): 859-877.

[5] Avolio, B. J., Bass, B. M. and Jung, D. I. 1999. Re-examining the Components of Transformational and Transactional Leadership Using the Multifactor Leadership Questionnaire. Journal of Occupational and Organizational Psychology. 72: 441-462.

[6] Barclay, D.W., Higgins, C. and Thompson, R. 1995. The Partial Least Squares Approach to Causal Modeling: Personal Computer Adoption And Use As Illustration. Technology Studies. 2(2): 285-309.

[7] Barney, J. B.: 1986. Organizational Culture: Can it be a Source of Sustained Competetive Advantage? Academy of Management Review 11(3): 656-665.

[8] Barret, R. 2009. Building a Vision-Guided, Values-Driven Organization', in Liberating the Corporate Soul: Building a Visionary Organization, by Richa Barret at www.power-projects.com. 
[9] Bass, B. M. 1985. Leadership and Performance Beyond Expectations New York: Free Press.

[10] Bass and Avolio. 1993. Transformational Leadership and Organizational Culture. Public Administration Quarterly. 17(1): 112121

[11] Brewer, P. D. and Brewer, K. L. 2010. Knowledge Management, Human Resource Management and Higher Education: A Theoretical Model. Journal of Education for Business. 85: 330-335.

[12] Breakwell, G. M., and Tytherleigh, M. Y. 2010. University Leaders and University Performance in the United Kingdom: Is It 'Who' Leads, or 'Where' They Lead That Matters Most? Higher Education. 60: 491506 .

[13] Bruno, L. F. C. 2011. Relationship Between Organizational Culture and Innovation Management: An Exploratory Investigation. Fundação Dom Cabral Internal Publication.

[14] Burns, J. M. 1978. Leadership. New York: Harper \& Row.

[15] Cameron, K. S., and Quinn, R. E. 1999, Diagnosing and Changing Organizational Culture: Based on the Competing Values Framework, (Addision-Wesley, Reading, MA). In Branson, C. M. 2008. Achieving Organisational Change Through Values Alignment. Journal of Educational Administration. 46(3): 376-395.

[16] Carmeli, A. and Tishler, A. 2004. The Relationship Between Intangible Organisational Elements and Organisational Performance. Strategic Management Journal. 25: 1257-1278.

[17] Carmen, C. O., Maria de la Luz, F. A. and Salustiano, M. F. 2006 , Influence of Top Management Team Vision and Work Team Characteristics on Innovation - The Spanish Case. European Journal of Innovation Management. 9(2): 179-201.

[18] Chao, C. Y., Lin, Y. S., Cheng, Y. L. and Tseng, Y. C. 2011. Employee Innovation, Supervisory Leadership, Organisational Justice and Organisational Culture in Taiwan's Manufacturing Industry. African Journal of Business Management. 5(6): 2501-2511.

[19] Chin. W.W. 1998. The partial least squares approach to structural equation modeling', in George A. Marcoulides, (eds.), Modern Methods for Business Research. Mahwah, NJ: Lawrence Erlbaum. 295-358.

[20] Compeau, D., Higgins, C.A. and Huff, S. 1999. Social Cognitive Theory And Individual Reactions to Computing Technology: A Longitudinal Study. MIS Quarterly. 23(2). 145-158

[21] Cormican, K. and O'Sullivan, D. 2004. Auditing Best Practice for Effective Product Innovation Management. Technovation. 24: 819-829.

[22] Creswell, J. W. 1998. Qualitative Inquiry and Research Design: Choosing Among Five Traditions (SAGE Publication, London).

[23] Damanpour, F. and Schneider, M. 2006. Phases of the Adoption of Innovation in Organisations: Effects of Environment, Organisation and Top Managers. British Journal of Management. 17: 215-236.

[24] de Hoogh, A. H. B, den Hartog, D. N., Koopman, P. L., Thierry, H., van den Berg, P.T., van der Weide, J.G. and Wilderom, C. P. M. 2004 Charismatic Leadership, Environmental Dynamism and Performance. European Journal of Work and Organisational Psychology. 13(4): 447471.

[25] Drucker, P. F. 1994. The Theory of Business. Harvard Business Review. 72(4): 95-104.

[26] Fiedler, F. E. 1967. A Theory of Leadership Effectiveness. New York: Mcgraw-Hill Book Co.

[27] Fornell, C. and Larcker, D. F. 1981. Structural Equation Models with Unobservable Variables and Measurementerror: Algebra and Statistics. Journal of MarketingResearch. 18(3): 328-388.

[28] Giampetro-Meyer, A., Brown, T., Browne, S. J. M. N. and Kubasek, N. 1998. Do We Really Want More Leaders in Business? Journal of Business Ethics. 17(15): 1727-1736.

[29] Graber, D. R. and Kilpatrick, A. O. 2008. Establishing Values-based Leadership and Value Systems in Healthcare Organizations. Journal of Health and Human Services Administration. 31(2): 179-197.

[30] Hair, J. F., Black, W. C., Babin, B. J. and Anderson, R. E. 2010 , Multivariate Data Analysis. $7^{\text {th }}$ edition. Upper Saddle River, NJ: Prentice Hall

[31] Henseler, J., Ringle, C.M. and Sinkovics, R. 2009. The use of partial least squares path modeling in international marketing. In Rudolf $\mathrm{R}$ Sinkovics and Pervez N. Ghauri (eds.). Advances in International Marketing. 20: 277-320.

[32] Howell, J. M. and Higgins, C. A. 1990. Champions of Technological Innovation. Administrative Science Quarterly. 3: 317-341.

[33] Iacobucci, D., Grisaffe, D., Duhachek, A. and Marcati, A. 2003. FACSEM: A Methodology for Modeling Factorial Structural Equations
Models, Applied to Cross-Cultural and Cross-Industry Drivers of Customer Evaluations. Journal of Service Research. 6(1): 3-23.

[34] Innovation \& Business Skills Australia Ltd, 2004, www.ibsa.org.au. [Accessed on September 2011].

[35] Jaskyte, K. 2004. Transformational leadership, organizational culture and innovativeness in nonprofit organisations. Nonprofit Management \& Leadership. 15(2): 153-168.

[36] Job and Bhattacharyya. 2007. Creativity and Innovation for Competitive Excellence in Organizations. Conference on Global Competition \& Competitiveness of Indian Corporate. 53-63.

[37] King, N. 1990. Modeling the Innovation Process: An Empirical Comparison of Approaches. Journal of Occupational and Organisational Psychology. 65(2): 89-101.

[38] Kotter, J. 1998. Cultures and Coalitions. In R Gibson (ed.), Rethinking the future; Rethinking Business, Principles, Competition, Control and Complexity, Leadership, Markets and the World. London: Nicholas Brearly Publishing Ltd.

[39] Kotter, J. P. and Heskett, J. L. 1992, Corporate Culture and Performance. New York: Free Press.

[40] Lakhal, L., Pasin, F. and Limam, M. 2006. Quality Management Practices and Their Impact on Performance. International Journal of Quality and Reliability Management. 23(6): 625-646.

[41] Morcillo, P., Rodriguez-Anton, J. M. and Rubio, L. 2007. Corporate Culture and Innovation: In Search of the Perfect Relationship. International Journal of Innovation and Learning. 4(6): 547-70.

[42] Muijs, D. 2011. Leadership and Organisational Performance: From Research to Prescription? International Journal of Educational Management. 25(1): 45-60.

[43] Nunally, J. C. and Bernstein, I. H. 1994. Psychometric Theory. New York: McGraw-Hill.

[44] Ogbonna, E. and Harris, L.C. 2000. Leadership Style, Organizational Culture and Performance: Empirical Evidence From UK Companies. International Journal of Human Resource Management. 11(4): 766788 .

[45] Osborne, S. P. 1998. Naming the Beast: Defining and Classifying Service Innovations in Social Policy. Human Relations. 51: 1133-1155.

[46] Panayides, P. 2006. Enhancing Innovation Capability Through Relationship Management and Implicationsfor Performance. European Journal of Innovation Management. 9(4): 466-483.

[47] Parry, K.W. 2002. Leadership, Culture and Work Unit Performance in New Zealand. IFSAM Conference.

[48] Peters, T. J. and Waterman, R. H. Jr. 1982. In Search of Excellence: Lessons from America's Best Run Companies. New York: Harper Collins

[49] Ringle, C. M., Wende, S. and Will, A. 2005. SmartPLS 2.0 M3, Available at http:// www.smartpls.de.

[50] Russell, R. F. 2001. The Role of Values in Servant Leadership. Leadership \& Organisation Development Journal. 22(2), 76-83.

[51] Schein, E.H.: 2004, Organisational culture and leadership, $3^{\text {rd }}$ edition (John Wiley \& Sons, San Francisco).

[52] Schin, J. and McClombe, G.E.: 1998, 'Top Executive Leadership and Organisational Innovation: An Investigation of Nonprofit Human Service Organisations', Social Work Administration 22(3): 1-21.

[53] Sobel, M. E. 1982. Asymptotic Confidence Intervals for Indirect Effects in Structural Equation Models. In S. Leinhart (ed.). Sociological Methodology. San Francisco: Jossey-Bass. 290-312.

[54] Taatila, V. P., Suomala, J., Siltala, R. and Keskinen, S. 2006 , Framework to Study the Social Innovation Networks. European Journal of Innovation Management. 9(3): 312-326.

[55] Tenenhaus, M., Esposito Vinzi,V., Chatelin,Y.-M. and Lauro, C. 2005. PLS Path modeling. Computational Statistics \& Data Analysis. 48(1): 159-205.

[56] Trice, H. and Beyer, J. 1993. The Cultures of Work Organisations Englewood Cliffs: NJ Prentice Hall.

[57] Van de Ven and Andrew, H. 1986. Central Problems in the Management of Innovation. Management Science. 32(5): 590-607.

[58] Wetzels, M., G. Odekerken-Schöder and C. van Oppen. 2009. Using PLS Modeling for Assessing Hierarchical Construct Models: Guidelines and Empirical Illustration. Management Information Systems Quarterly. 33(1): 177-195

[59] Xenikou, A. and Simosi, M. 2006. Organizational Culture and Transformational Leadership as Predictors of Business Unit Performance. Journal of Managerial Psychology. 21(6): 566-579. 